\title{
IPM Technique to Prevent Fruit Fly Damage of Mango
}

\author{
R.P. Sharma ${ }^{1}$, Govind ${ }^{2}$ and B.D. Singh ${ }^{3^{*}}$ \\ ${ }^{1}$ SMS Plant Protection, KVK, Madhepura, India \\ ${ }^{2}$ SMS Agronomy, KVK, Purnia, India \\ ${ }^{3}$ SMS Agril. Extension, KVK, Patna, India \\ *Corresponding author
}

\section{A B S T R A C T}

\begin{tabular}{|l|}
\hline K e y w o r d s \\
$\begin{array}{l}\text { Mango, Mango fruit fly, } \\
\text { Control measures }\end{array}$ \\
\hline Article Info \\
\hline $\begin{array}{l}\text { Accepted: } \\
\text { 04 October } 2018 \\
\text { Available Online: } \\
\text { 10 November } 2018\end{array}$ \\
\hline
\end{tabular}

Keywords

Mango, Mango fruit fly, Control measures

Article Info

Accepted: Available Online:

Novenber 2018

\begin{abstract}
The mango fruit fly Bactocera dorsalis (Hendel) (Diptera: Tephnidae) is believed to be the single most devastative pest of mango in Bihar. It accounts for about 27 per cent of harvesting loss. The flies attack semi ripe and mature fruits during the months of April and May. On Farm Trail conducted at 14 farmers plot of Kishanganj district, fly monitoring and fruit infestation estimation were recorded during the two experimental seasons 201213 and 2013-14. Maximum (33\%) fruit fly infestation recorded where no any control measures or spray of chemical applied for population (Farmers Practice). Use of commercial fruit fly lure@5/acre + spray of Rogor 30 Ec @ $1.5 \mathrm{ml}$ at the time of peanut size fruits show noticeable reduction of fruit fly percent infestation on fruit and also receive maximum (3.09) B:C ratio which also support the finding of Ray et al., (2016).
\end{abstract}

\section{Introduction}

Mango fruit fly which is commonly known as oriental fruit fly Bactocera dorsalis (Hendel) (Diptera: Tephnidae) is the most devastative pest of mango in Bihar. The Fruit flies (Diptera: Tephritidae) are considered the most destructive insect pests of fruits and vegetables in the world. The hosts of these flies belong to a wide variety of families of plants, and include many major commercial crops (Vayssieres et al., 2008; Salem and Abd-El- Salam, 2013). Without flies control, direct damage has been reported from 30 to $80 \%$ depending on the fruit, variety, location and fruit season (Mwatawala et al., 2006). Fruit flies often cause serious damage to mango; owing to their attack the highest damage observed in mango was $56.5 \%$ (Jose et al., 2013). The mango fruit fly is believed to be the single largest crop damager in India. It accounts for about 27 per cent of harvesting loss. The flies attack semi ripe and mature fruits during the months of April and May. Other fruits like guava, citrus, plum, peach, sapota, loquot, etc are also susceptible to this pest attack. Damage is caused both by adults and maggots. Adult female punctures the rind of near ripe fruits with its needle like ovipositor and lays eggs. The legless yellowish maggots after hatching bore and feed on fruit pulp and on maturity come out of the fruit, drop on the ground and pupate deep under the soil. Thus the maggots destroy the pulp making it foul smelling and discolored. Infested fruits develop brown rotten patches 
on them and fall to the ground ultimately. (Jayraj and Yansundaram, 2015) the reduction of the quality and quantity of marketable mango fruit due to fruit fly infestation impacts negatively on farmers through revenue losses. However, little is known about the magnitude and economic value of losses incurred at the farm level as a result of this infestation. While farmers perceive pesticides as ineffective in combating the fruit fly menace; however, they continue to rely on them because costeffective and environment friendly alternative control measures are not available to them (Varela et al., 2006). With time, pests develop resistance to pesticides which causes rising pest populations and necessitates increasing chemical applications over time at increased costs. Integrated pest management (IPM) strategies; a combination of more effective and efficient methods referred to as an IPM package have been found to be superior to pesticides in fruit fly control. There are so many tactics available in market which confuses the farmer to easily adopt and apply on their orchards.

Keeping in view KVK Kishanganj conducted on farm trial on 14 farmers mango orchards during year 2012-13 and 2013-14 to develop IPM technique for preventing fruit fly damage specially through use of pheromones.

\section{Materials and Methods}

For conducting on farm trail at different locations of 14 farmers plot of Kishanganj district, fly monitoring and fruit infestation estimation were recorded during the two experimental seasons 2012-13 and 2013-14. The experimental area was comprised about 0.5-1.0 acres (fourteen replicates i.e. fourteen farmers plots) of Mango orchard grown with variety mainly "Surjapuri", and field tests were conducted with three technological options $\mathrm{T} 0=$ No any measure or spray (farmers practice), $\mathrm{T} 1=$ Use of commercial fruit fly lure @ 5/acre and T2 = Use of commercial fruit fly lure@ 5/acre + spray of Rogor30 EC @ $1.5 \mathrm{ml}$ at the time of peanut size fruits. The traps made of plastic material and hung in tree were distributed in a completely randomized block design. All the traps were hanged at about $3 \mathrm{~m}$ height in a shady place of the mango trees.

The samples of mango fruit were collected weekly for checking pest infestation symptoms and noting fruit fly infestation. The percentage fly infestation for mango fruit was examined randomly by analyzing a total of 100 fruits, and numbers of healthy fruits and fruits showing fruit fly oviposition marks (damaged and undamaged fruits) were counted.

For assessing fruit fly infestations, from total numbers of fruits observed subtracted the numbers of infested fruits counted and then percent infestation was calculated by following the formula (Anon, 2007 for stem borer infestation).

\section{Numbers of infested fruits \\ Per cent infestation = ------------------ X 100 \\ Total numbers of fruits}

Data obtained on fruit infestation estimation were statistically analyzed the data means were compared according to ANOVA.

\section{Results and Discussion}

The obtained data as shown in Table 1, indicated that fruit fly infestation recorded maximum $(33 \%)$ in farmers practice in which no any control measures or spray of chemical applied for population management of fruit fly whereas technological option T1 (Use of commercial fruit fly lure @ 5/acre) reduce the population of fruit fly and finally minimize the fruit infestation up to $8 \%$. 
Table.1 Evaluation of technological options for management of mango fruit fly

\begin{tabular}{|c|c|c|c|c|c|c|c|c|}
\hline Technological Option & $\begin{array}{l}\% \\
\text { infesta } \\
\text { tion }\end{array}$ & $\begin{array}{l}\text { Av. } \\
\text { Yield } \\
\text { (q/ha) }\end{array}$ & $\begin{array}{c}\% \\
\text { Increa } \\
\text { se in } \\
\text { Yield }\end{array}$ & $\begin{array}{c}\text { Cost of } \\
\text { interve } \\
\text { ntion } \\
\text { (ha) }\end{array}$ & $\begin{array}{l}\text { Cost of } \\
\text { producti } \\
\text { on (Rs } \\
\text { /ha) }\end{array}$ & $\begin{array}{l}\text { Gross } \\
\text { Return } \\
\text { (Rs /ha) }\end{array}$ & $\begin{array}{l}\text { Net } \\
\text { Return } \\
\text { (Rs /ha) }\end{array}$ & $\begin{array}{l}\text { B:C } \\
\text { ratio }\end{array}$ \\
\hline $\begin{array}{l}\text { T0 }=\text { No any measure or } \\
\text { spray of any chemical } \\
\text { (Farmer's Practice) }\end{array}$ & 33.00 & 57.00 & 0.00 & 0.00 & 52000 & 114000 & 62000 & 2.19 \\
\hline $\begin{array}{l}\text { T1 = Use of commercial } \\
\text { fruit fly lure @ } 5 / \text { acre }\end{array}$ & 8.00 & 74.00 & 29.82 & 1620 & 53620 & 148000 & 94380 & 2.76 \\
\hline $\begin{array}{l}\text { T2= Use of commercial } \\
\text { fruit fly lure@ } 5 / \text { acre + } \\
\text { spray of Rogor } 30 \text { Ec @ } \\
1.5 \text { ml at the time of } \\
\text { peanut size fruits }\end{array}$ & 1.00 & 85.00 & 49.12 & 3000 & 55000 & 170000 & 115000 & 3.09 \\
\hline $\begin{array}{l}\text { CD at } 5 \% \\
\text { SEm } \\
\text { CV }\end{array}$ & $\begin{array}{l}1.98 \\
0.47 \\
4.68\end{array}$ & $\begin{array}{l}1.83 \\
0.43 \\
2.39\end{array}$ & & & & & & \\
\hline
\end{tabular}

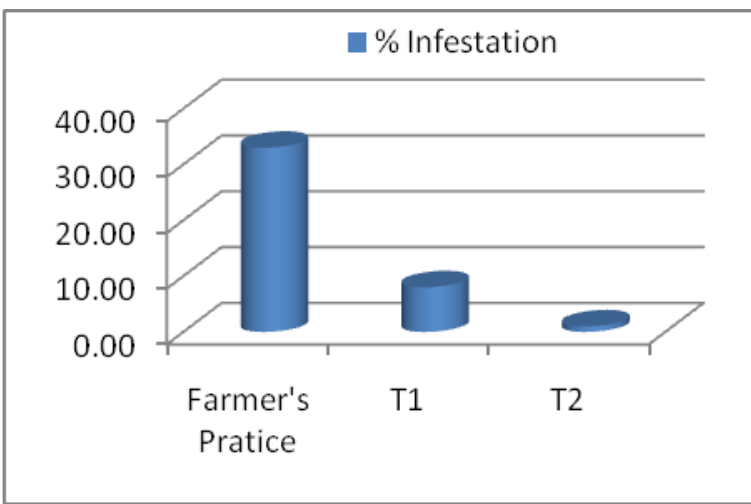

The T2 i.e. Use of commercial fruit fly lure@ 5/acre + spray of Rogor 30 Ec @ $1.5 \mathrm{ml}$ at the time of peanut size fruits show noticeable reduction of fruit fly percent infestation on fruit. All technological options showed statistical significant difference among them.

So far yield is concern $\mathrm{T} 1$ showed 29.82 per cent increase in fruit yield while $\mathrm{T} 2$ showed maximum percent increase of yield i.e. $49.12 \%$. On comparison of $\mathrm{B}: \mathrm{C}$ ratio $\mathrm{T} 2$ receive maxim mum (3.09) closely followed by $\mathrm{T} 1$ and Farmers practice (T0) that is 2.76 and 2.19 , respectively.

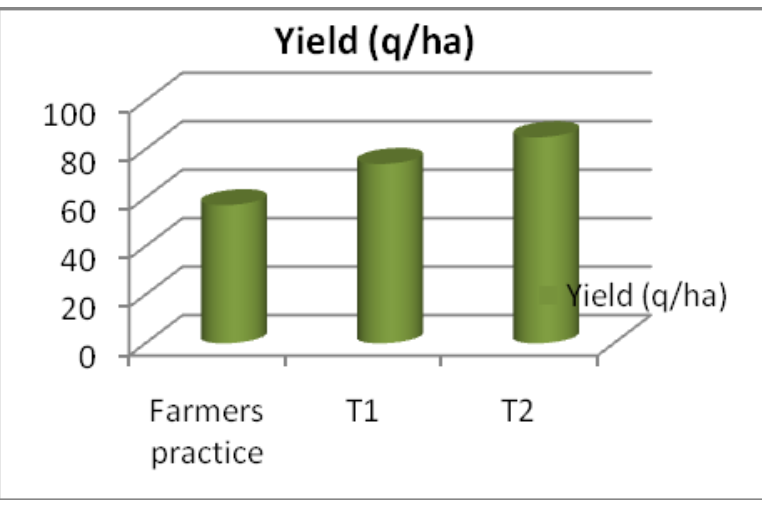

On the basis of evaluation of different technological options we conclude that farmer can effectively prevent the losses caused by mango fruit fly by use of commercial fruit fly lure@5/acre + spray of Rogor 30 Ec @ 1.5 $\mathrm{ml}$ at the time of peanut size fruits which also support the finding of Ray et al., 2016.

\section{References}

Jayaraj J., Professor and Dr. M. Kalyanasundaram, 2015. Department of Entomology. Agricultural College and Research Institute, Madurai 625 104, 
Phone No. 0452-2422956, extn.214, email: agentomac@tnau.ac.in)

Jose L, Cugala D, Santos L (2013). Assessment of Invasive Fruit Fly Fruit Infestation and Damage in Cabo Delgado Province, Northern Mozambique. African Crop Science Journal, 21 (1): 21-28.

Mwatawala MW, De Meyer M, Makundi RH, Maerere AP (2006). Seasonality and host utilization of the invasive fruit fly, Bactrocera invadens (Dipt., Tephritidae) in Central Tanzania. Journal of Applied Entomology, 130 (910): 530-537.

Ray, S.N; Tamoghna, S and Nithya, C. 2016. Evaluation of pheromone traps against mango fruit fly, Batocera dorsalis (Hendel) (Diptera: Tephritidae), Indian Jounal of Entomology, 78 (2): 174-176.

Salem SA, Abd-El Salam AME (2013). Field evaluation and efficacy of different natural and sex attractant traps for attracting the adults of med and peach flies, Ceratitis capitata (Wied.) and Bactrocera zonata (Saunders).
Canadian Journal of Plant Protection, 1 (5): 167-171.

Salem SA, Abd-El Salam AME (2013). Field evaluation and efficacy of different natural and sex attractant traps for attracting the adults of med and peach flies, Ceratitis capitata (Wied.) and Bactrocera zonata (Saunders). Canadian Journal of Plant Protection, 1 (5): 167-171.

Varela, A.M, A. Seif and B. Nyambo. (2006). A guide to IPM in mango production in Kenya. The International Centre of Insect Physiology and Ecology. 2nd edition. ICIPE Science Press.

Varela, A.M, A. Seif and B. Nyambo. (2006). A guide to IPM in mango production in Kenya. The International Centre of Insect Physiology and Ecology. 2nd edition. ICIPE Science Press.

Vayssieres JF, Sinzogan A, Adandonon A (2008). The new invasive fruit fly species, Bactrocera invadens Drew Tsuruta and White. IITA-CIRAD Leaflet No. 2. p 4.

\section{How to cite this article:}

Sharma, R.P., Govind and Singh, B.D. 2018. IPM Technique to Prevent Fruit Fly Damage of Mango. Int.J.Curr.Microbiol.App.Sci. 7(11): 30-33. doi: https://doi.org/10.20546/ijcmas.2018.711.005 